\title{
English Communication Skills and the Needs of Engineering Students
}

\author{
B. Sanyasi Rao, I. S. V. Manjula, G. Suvarna Lakshmi
}

\begin{abstract}
English language is both a lingua franca and a library language in India. It plays a predominant role in Indian higher education, particularly for engineering education. English language is crucial for engineering students not only for academic excellence but also for career advancement. English for engineering students is a platform, where they could share feelings, exchange ideas and interact with each other to better their academic standards and careers progression. English, a widely spoken language in the world, is more important for Indian engineering students as they are expected to work anywhere in and out of India, where English is a medium of communication in the workplace.
\end{abstract}

Key Words: Lingua Franca, Library Language, Engineering Students, academic excellence \& workplace.

\section{INTRODUCTION}

Engineering is one of the largest realms of study, where the maximum subject knowledge is available in English language. In the realm of engineering education, English language is used as common medium of communication throughout the world both for acquiring subject knowledge and for publishing their research reports, writing projects, presentations, debates, discussions and so on . English language is a predominant factor as it is the medium of instruction, to acquire subject knowledge from written material and to secure a job for themselves. Mr. Rup Narayan Shrestha \& et al. (2015) comment, [1] 'Without English communication skills, engineering students may find themselves difficult to digest the concepts taught and to secure a job for themselves after completion of the course'. Nandan Nilekani (2017), the CEO and co-founder of Infosys, while addressing the graduating students in IIT (Madras) convocation Ceremony, commented, [2] 'Machines are becoming an integral part of technologies. However, they will never take control over the jobs that involve people to do. Therefore strong communication skills are basic pillar of soft skills, which can make them collaborate and work as team'. Engineering students should have English language competence to augment the academic performance and career advancement. With superior English communication skills, engineering students are triplebenefitted i.e. for academics, for securing a job for themselves and for their career advancement.

Revised Manuscript Received on January 03, 2020.

* Correspondence Author

B. Sanyasi Rao*, Associate Professor, English, NS Raju Institute of Technology, Visakhapatnam.

Dr. I.S.V. Manjula, Professor, English (ratified by JNTUK) and a Trainer of Master Trainers (TOT), JNTU, Kakinada,

Dr. G. Suvarna Lakshmi, Asso.Professor and Head, Department of ELT, SDE, Visakhapatnam.

(C) The Authors. Published by Blue Eyes Intelligence Engineering and Sciences Publication (BEIESP). This is an open access article under the CC BY-NC-ND license (http://creativecommons.org/licenses/by-nc-nd/4.0/)

\section{ENGLISH COMMUNICATION SKILLS FOR ENGINEERING STUDENTS' ACADEMIC EXCELLENCE}

Most scientific and technological papers and journals are available in English language in the world.

Almost all the books, related to engineering subjects are written in English only. Rup Narayan Shrestha et al. (2015) comment [1], 'The medium of instruction in the engineering colleges is commonly English'. Prof. V. Chandra Sekhar Rao (2017) opines, [3] 'Engineering students are required to be good at English language both for academic needs and for their employability skills'. K. Latha (2014) opines, [4] 'English language is tool that affects engineering students' academic life, where they deal with countless lectures in the classroom, instructions in laboratory, project reports and paper publications. Most of the engineering classroom teaching is held on in English language. It requires having good command over English communication skills'. Engineering students mainly depend on internet source to get basic idea about their subject knowledge. Most of the information, Internet provides is in English. Ms. Mane Varsharani Shamrao (2017) states, [5] 'The most convenient source of information that Internet provides is in English'. In addition to, to go for higher education abroad, engineering students need have to take up standardize tests, TOEFL, IELTS, GRE, GMAT, PTE etc... to prove their English language proficiency. The tests play a pivotal role in getting an admission in foreign universities. K. Latha (2014) opines, [4] 'Speaking in English effectively is a significant criterion for admission process and a candidate's capability to master English language skills and betters their chances of admissions in foreign Universities'.

\section{ENGLISH COMMUNICATION SKILLS FOR EMPLOYABILITY OF ENGINEERING STUDENTS}

The advancement of Science and Technology brings a new scope for engineering courses and the importance of engineering has been gradually flowering in the contemporary world. Along with technical skills of the engineering graduate, effective English communication skills are also desired as they are supposed to work in the global context. Prof. Gurucharan Singh (2018), Vice President - Corporate Affairs, HR \& Training, Cambridge Institute of Technology says [6] 'Globalization demands quality engineering graduates. It requires focus on progress of generic skills, application skills, problem-solving skills, communication skills and technical skills of the entry-level engineering graduates'. The Deccan Herald (2012), published an article bearing the title, 'Importance of English in employment'.

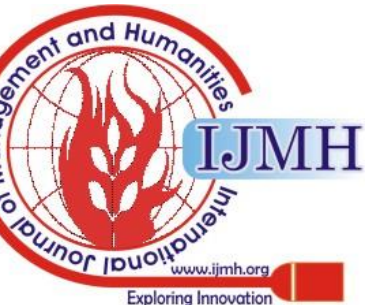




\section{English Communication Skills and the Needs of Engineering Students}

It says, [7] 'English Communication skills are greatly important for one's professional development. And the ability of communicating in English properly well both in written and in verbal is greatly necessary for the career advancement of engineering students'.

The Economic Times (2018) posted editorial, states [8] 'Those who speak English fluently earn up to $34 \%$ more than others: Study'. Amit Sharma (2018), research analyst, National Council for Applied Economic Research \& Dr Abusaleh Shariff (2018), Centre for Research \& database in Development Policy, New Delhi opine, [8] 'Men who speak in English fluently receive income up to 34\% higher; men who speak a little English language earn wages up to $13 \%$ higher than those who cannot speak in English at all. If engineering students are poor in English communication skills, they have lesser scope of employability'. Aspiring Minds' National Spoken English Skills (SES) Report discloses [9] ' $52 \%$ of engineering graduates are not employable for any position in the knowledge economy due to their poor spoken communication skills'. Industry always whines about the poor communication skills of the engineering graduates. Dr. Meenu Pandey \& Dr. Prabhat Pandey (2014) comment, [10] 'The ability to use English language effectively is seriously required to remain employable'. National Educational Policy - 2019 reports, [11] 'Many surveys of employers all over the world disclose that English spoken skills are positioned first amongst the candidates' highly essential skills and qualities'. D. Venkateswar Rao (2015) comments, [12] 'For technical graduates English communication skills are required more than their subject-knowledge'. B. Nagia (2016) mentions, [13] 'Whatever the career you wish for, whether it is Engineering or History, having a good command over English language will greatly augment your chances of success'. In the view of Zedeck and Goldstein (2000) [14], 'Communication skill is the foremost priority among other skills in recruiting the candidates'. India Skills Report 2019 says [15] 'English communication skills is one of the top 3 skills, employers look for'. A. Clement \& T. Murugavel (2015) comment, [19] 'Students of engineering are confronted with tough and difficult recruitment process, in that they have to prove their command over English communication skills'. Hence engineering graduates are expected to have good technical skills along with sound English communication skills by the employers of engineering industry. It is a well-known fact that English Communications Skills enhance the academic excellence, quality of employability and career advancement of the engineering students.

\section{ENGLISH COMMUNICATION SKILLS FOR AUGMENTATION OF ENGINEERING CAREER}

Effective communication skills in English, even after getting a job helps engineering graduates pave a better path for their career. K. Latha (2014) opines, [4] 'Even after getting a job, engineering graduates are obliged to work in teams since individual efforts are seldom successful. A great number of Indian engineers have to voyage to many continents and work away from their home country'. Engineering graduates are expected to work with team members, who hail from varied languages and cultural milieu, where English works as a lingua franca. Dr. E.
Suresh Kumar (2015), Professor and Head of English, Osmania University, comments, [16] 'Effective communication skills enhance professional competence'. Employers value those employees, who have effective communication skills as the employees need to interact with coworkers, engage in debates, contribute in meetings \& committees, listen to and convey information clearly and pass instructions effectively well. Now-a-days, engineers have to communicate with their counterparts and colleagues in English. 'Among most of the professionals like the scientists, technologists and business experts who belong to diverse cultural and linguistic milieus, English is chiefly considered to be a language of communication' (www.careerindia.com) [17].

\section{CONCLUSION}

English Communications Skills are badly important for engineering students and benefit them in three ways. Firstly an expected level of in English language proficiency would be essential for engineering students as major part of the theory is taught in English language. To study abroad in some of the best universities in the world, students have to take up standardized tests to prove their English language proficiency. These tests play a major role for admissions to most of the universities overseas. In addition to, today's engineers have to communicate in English with their colleagues and counterparts across the globe. Among the most of the professionals like the scientists, technologists and business connoisseurs who belong to various cultural and linguistic milieu, English is largely taken into consideration as a language of communication. Hence desired English communication skills are expected by the companies and HR Managers during the interviews. Finally, after having secured a job, English communication skills are vital to sustain and to be successful in the career at the workplace.

\section{For academic excellence}

- To digest the concept taught by the teachers in the classroom.

- For communication purpose (as English is predominantly considered to be a language of communication).

- To produce clear technical documents

- To understand and write academic reports.

- To understand technical papers or journals written in English.

- To contribute to presentations, debates and discussions.

- $\quad$ To read books with international standards.

- To go for further studies abroad in some of the best universities in the world (students have to take up standardized tests to prove their English language proficiency)

\section{For holding employability}

- To augment confidence in various engineering contexts

- $\quad$ To acquire the potentiality of employability.
Published By: \& Sciences Publication (C) Copyright: All rights reserved.
Blue Eyes Intelligence Engineering

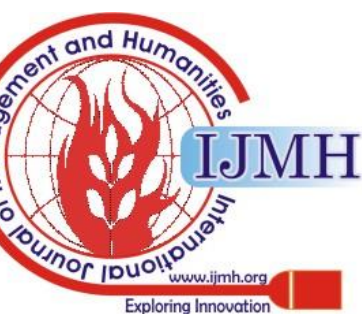




\section{For the career advancement}

- To be professional at workplace ambiance.

- To communicate with their colleagues in their workplace and with their counterparts across the world so as to build a strong interpersonal relations among the peers, colleagues and counterparts.

- To sustain in the workplace successfully well.

- $\quad$ To achieve prospective \& Progressive career.

But Dearth of English communication skills of engineering students is openly revealed in some of the surveys, made in India. AMCAT Report - 2019 says [18], 'About $90.92 \%$ of engineering graduates do not possess the desired programming and algorithm skills required to serve IT product companies, whereas $55.90 \%$ show dearth of soft skills and $65.14 \%$ fall short of cognitive skills'. Marc J. Riemer (2002) opines, [20] 'Subject knowledge and technical skills are evidently significant but those must be exposed with effective communication skills, in particular with oral skills, which decide students' success or failure in career'.

\section{REFERENCES}

1. Rup Narayan Shrestha, Bharat Raj Pahari and Jai Raj Awasthi (2015), "Impact of English on the Careers of Engineering Students: A Brief Overview on G(local) Context", Journal of the Institute of Engineering, Vol-2, Issue-1 (pp.182-188).

2. https://economictimes.indiatimes.com/magazines/panache/times-area-changin/articleshow/60746038.cms

3. Prof. V. Chandra Sekhar Rao (2017), "A Model English Syllabus Design for the Students of Science and Technology", Journal for research Scholars and Professors of English Language Teaching, Vol1 , Issue- 3 .

4. K. Latha (2014), "Role of English Language for Engineering Students", American International Journal of Research in Humanities, Arts and Social Sciences, (pp.122-123) Available online at http://www.iasir.net

5. Ms. Mane Varsharani Shamrao, "Importance of English Communication for Engineering Students from Rural Areas and Its Remedies", IOSR Journal of Mechanical and Civil Engineering (IOSR-JMCE), PP: 39-42

6. https://in.linkedin.com/in/gurucharan-singh-04607618

7. https://www.deccanherald.com/content/249714/importance-englishemployment.html

8. https://economictimes.indiatimes.com/jobs/those-who-speak-englishfluently-earn-up-to-34-more-than-othersstudy/articleshow/28426329.cms

9. https://www.aspiringminds.com/blog/research-articles/study-onspoken-english-skills-of-engineers/

10. Dr. Meenu Pandey \& Dr. Prabhat Pandey (2014), "Better English for Better Employment Opportunities", International Journal of Multidisciplinary Approach and Studies, Volume -01, No.4, July Aug 2014, (pp.417-426).

11. National Educational Policy - 2019 (p.90)

12. Venkateswar Rao. D (2015), "Teaching English Communication Skills for Professional Students", Indo - Asian Journal of Multidisciplinary Research (IAJMR), Vol-1, Issue-2, Year - 2015, (pp.125 - 131) Available online www.jpsscientificpublications.com

13. Nagia, B. (2016), "Prominence of English Language for Career Development", Language in India, Vol-16, No. 4, April 2016 (pp3442)

14. Zedeck, S., \& Goldstein, I. L. (2000). Sliding bands: An alternative to top-down selection. In R. Barrett (Ed). Handbook of fair employment strategies. Westport, CT: Courum Books.

15. India Skills Report 2019 (p.38)

16. https://www.sakshieducation.com/Engineering/Story.aspx?nid=10676 8\&cid $=12 \&$ sid $=726 \&$ chid $=1325 \&$ tid $=0$

17. https://www.careerindia.com/tips/how-important-is-english-languagefluency-for-engineers-011550.html

18. Aspiring Minds National Employability Report - 2019 (P.17)

19. Clement. A \& Muruguvel. T (2015), English for Employability: A case Study of the English Language training Need Analysis for
Engineering Students in India, English Language Teaching, published by Canadian centre of Science and Education Vol. 8, No. 2.

20. Marc J. Riemer (2002), "English and Communication Skills for the Global Engineer", Global J. of Engineering. Educ., Vol.6, No.1, Published in Australia.

\section{AUTHORES' PROFILE}

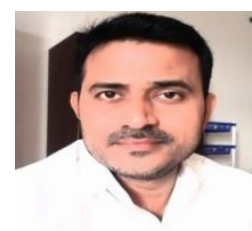

B. Sanyasi Rao, has bagged 17 years of experience in teaching English for undergraduate, graduates and postgraduate students in India and abroad. He is a research scholar, JNTU, Kakinada, EG \& Andhra Pradesh and an Associate Professor of English in NS Raju Institute of Technology, Visakhapatnam. He shoulders the onus of Training Head for CRT Programs. He gained a few years of experience as Verbal Trainer at IMS, Odisha, where he trained the students for CAT and GRE. He taught graduates in Al-Mergb University, Al-Khooms, Libya. His area of research is English Language Teaching (ELT)

Dr. I.S.V. Manjula, is a visiting Professor of English (ratified by JNTUK)

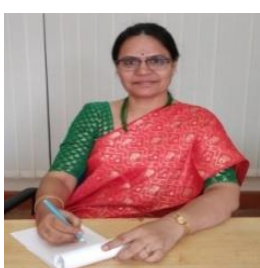
and a Trainer of Master Trainers (TOT) training employees, students and teaching fraternity of various organizations. She's a certified Examiner for IELTS. She's validated as Lead Trainer by British Council to train master trainers, teachers and leaders in Education Institutions. She's awarded Sri R. Venkataratnam Research Medal for Best Thesis for Ph.D. dissertation by AU. Her institution honored her with Pratibha Award. She's conducted 68 workshops and published severa research papers, poems and article. She presented papers in National and International Conferences. She's an invited speaker on Communication and Soft Skills in varied academic and industrial sectors. She's recognized Research Supervisor for JNTUK and SVU. She has professional Membership of IACLALS and ELTAI.

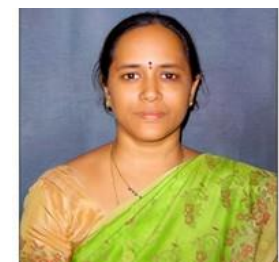

Dr. G. Suvarna Lakshmi, is an Asso.Professo and Head, Department of ELT, SDE. With a doctoral research focused on developing critical thinking skills in ESL/EFL learners, she's worked on varied research areas including materials, school education, technology supported learning, etc. She conducted many training workshops and presented research papers in 51 national and international conferences held in USA, Singapore, Libya, Malaysia and Australia and many of them are published in reputed journals. She has a very unique experience of English language teaching from primary school to Post Graduate level that included various teaching ESP courses, in addition to teacher the training programmes. She has also been guiding research in ELT. She contributed to Distance Education materials for 3 universities and co-authored textbooks, prescribed to UG courses across universities in combined AP state. 